\title{
Temporal Distribution of Fish Community Structure in Dongting Lake Estuary
}

\author{
Xiping Yuan'1, Xin Yang1, Hongzi Ge', Hong Li1, Daqing Deng² \\ ${ }^{1}$ Hunan Fisheries Institute, Changsha, China \\ ${ }^{2}$ Xinshao County Animal Husbandry and Fisheries Bureau, Shaoyang, China \\ Email: kerryuan@163.com
}

How to cite this paper: Yuan, X.P., Yang, X., Ge, H.Z., Li, H. and Deng, D.Q. (2019) Temporal Distribution of Fish Community Structure in Dongting Lake Estuary. Agricultural Sciences, 10, 294-301. https://doi.org/10.4236/as.2019.103025

Received: February 11, 2019

Accepted: March 10, 2019

Published: March 13, 2019

Copyright (c) 2019 by author(s) and Scientific Research Publishing Inc. This work is licensed under the Creative Commons Attribution International License (CC BY 4.0).

http://creativecommons.org/licenses/by/4.0/

(c) (i) Open Access

\begin{abstract}
The Dongting Lake Estuary is migration pathways for some river-lake migratory and semi-migratory fishes. In the present study, an annual survey of fish was conducted from January to November 2018 covering a total of 6 sites in Dongting Lake Estuary. A total of 57 freshwater species and subspecies belonging to 5 orders and 10 families were recorded. The catches at the Dongting Lake Estuary were mainly composed of Lake settled fish. The biomass of Cyprinus (Cyprinus) carpio Linnaeus was the highest, accounting for $25.53 \%$ of the total catches, followed by Hypophthalmichthys molitrixs, Culter alburnus Basilewsky and Ctenopharyngodon idellus, accounting for 10.41\%, $8.99 \%$ and $7.10 \%$ of the total catches, respectively. The four major domestic carps accounted for $26.13 \%$ of the total catch. The range of richness of species varied between 40 and 51 species. The trend was fewer species in spring, with the arrival of summer and autumn gradually increasing, peaking at the turn of summer and autumn, and then gradually decreasing with the arrival of winter, to the lowest in spring. The Shannon, Simpson, Pielou and Margalef indices showed the consistent trends with richness of species.
\end{abstract}

\section{Keywords}

Biodiversity, Dongting Lake Estuary, Freshwater Fish

\section{Introduction}

Dongting Lake is a large, shallow lake in northeastern Hunan Province, China. It is a flood basin of the Yangtze River [1]. Dongting Lake has a subtropical monsoon climate and its annual precipitation varies greatly. Hence, the lake's size depends on the season. The Dongting Lake Estuary is migration pathways for some river-lake migratory and semi-migratory fishes [2]. It is the gene pool for 
fishes and the representative of biological diversity of freshwater fishes in China. Dongting Lake is a place for fish breeding, fattening and wintering, in addition to regulating floods. It plays an extremely important role in protecting the fishery resources and biodiversity of the Yangtze River system [3] [4].

However, as the basin economy develops and human activities aggravate, the Dongting Lake Estuary is confronted with a series of problems of resources and environment such as water environment deterioration, ecological degradation and destruction of resources [5]. Over-fishing, sand excavation in channel and water pollution have brought about serious problems to Dongting Lake Estuary fish resources [6]. The number of species caught has gradually decreased.

In this study, an annual survey of the composition and diversity of fish communities in the Dongting Lake Estuary was carried out. The objectives are: 1) to characterize the fish fauna in Dongting Lake Estuary; 2) to know fish biodiversity and temporal distribution.

\section{Materials and Methods}

\subsection{Study Area}

The agricultural watershed, Located in northeastern Hunan Province, China,

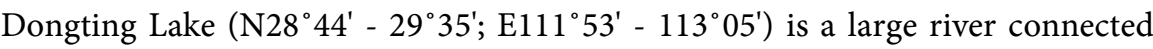
lake in the middle reaches of the Yangtze floodplain. The present study was conducted in the Dongting Lake Estuary, which is a channel of $14 \mathrm{~km}$ length and $1 \mathrm{~km}$ mean width, and the sampling area was close to Dongting brige, Chenglingji and Sanjiangkou (Figure 1).

\subsection{Sampling Methods}

Samplings of fish were conducted from January to November 2018, covering a total of 6 sites in Dongting Lake Estuary. Each site was carried out four times. The investigations were conducted by boat. In this way, information was obtained for each cienaga during the four characteristic periods of the hydrological cycle of the Dongting Lake Estuary. The fish were collected using experimental multifilament gillnets, formed from panels measuring $100 \times 3 \mathrm{~m}$, in nine different sizes (from 4 to $15 \mathrm{~cm}$ stretched mesh).

The nets were set out for $24 \mathrm{~h}$, and checked every $4 \mathrm{~h}$, with the intention of avoiding phenomenon such as predators and decomposition due to the high temperature of the water. In order to estimate the total richness of the species, sampling was designed for each of the various existing habitats. In all the cienagas, one sampling station was chosen within each of these four macrohabitats: littoral with trees, littoral without trees, pelagic, and the connecting channel between cienaga and main rivers. All were sampled simultaneously. Because sampling effort was constant across samples, it was not necessary to adjust diversity estimates using rarefaction or other techniques to account for different sampling techniques or sample sizes. 


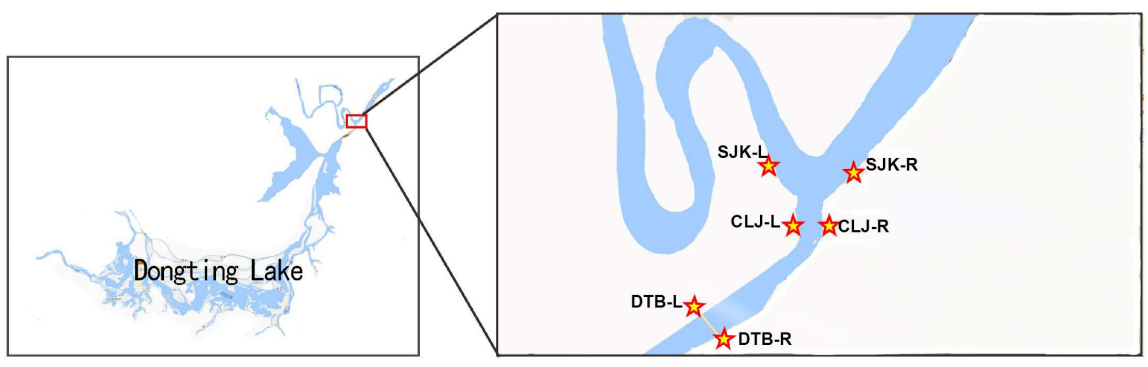

Figure 1. Sampling location of fishes in the Dongting Lake. SJK: San jiangkou, belonging to the Yangtze River main stream; $\mathrm{CJH}$ : Cheng lingji, belonging to the intersection of the Yangtze River and dongting lake; DTB: Dongting Bridge, belonging to the Dongting lake; $\mathrm{L}$ means left bank; $\mathrm{R}$ means right bank.

\subsection{Data Analyses}

After sampling a specific site, each individual was identified to the species level according to Chu et al. [7], FRL [8], HIH [9], and HIFS [10]. Most individuals were released after identification, whilst some other specimens were fixed with the $10 \%$ formalin for certain identification after anaesthesia by eugenol solution. All fixed specimens were preserved HNFRI, China.

We define the richness of species in a cienaga as Local Richness. Shannon-Wiener diversity $\left(H^{\prime}\right)$, Simpson, Pielou and Margalef indices were calculated from the taxonomic composition of cienagas samples [11]. The formulas were:

$$
P_{i}=N_{i} / N \times 100 \%
$$

Margalef index: $R=(S-1) / \ln N$;

Shannon-Wiener diversity $\left(H^{\prime}\right): H^{\prime}=-\sum P_{i} \cdot \log _{2} P_{i}$;

Simpson index: $D=1-\left(\Sigma P_{i}\right)^{2}$;

Pielou evenness index: $E=H / H \max$;

$H \max =\ln S$.

where $S$ is the number of species; $N$ is the number of individuals; $N_{i}$ is the number of the species $i$.

\section{Results}

\subsection{Estimating Total Species Richness}

During the study, a total of 5831 individuals were recorded representing 57 freshwater species and subspecies in Dongting Lake Estuary, which distributed among 5 orders and 10 families. Cypriniformes and Siluriformes were the most represented orders. The most diverse family was Cyprinidae with thirty-seven species (Table 1 and Figure 2).

As revealed by species accumulation curve (sample-based rarefaction curve, Figure 3) for all samples in Dongting Lake Estuary, species richness of fish community increased with increasing numbers of samples. However, the accumulation curve for species richness was nowhere near a complete asymptote in the present study (Figure 3). Thompson and Withers [12] present that site with 
Table 1. List of fish and its percentage of catch individual and weight.

\begin{tabular}{|c|c|c|c|c|c|}
\hline Species & Individual \% & Weight \% & Species & Individual \% & Weight \% \\
\hline Mylopharyngodon piceus (Rich.) & $0.54 \%$ & $3.97 \%$ & $\begin{array}{c}\text { Sarcocheilichthys sinensis sinensis } \\
\text { Bleeker }\end{array}$ & $0.32 \%$ & $0.03 \%$ \\
\hline Ctenopharyngodon idellus (C.et V.) & $1.58 \%$ & $7.10 \%$ & S.nigripinnis nigripinnis (Günther) & $0.22 \%$ & $0.01 \%$ \\
\hline Hypophthalmichthys molitrix (C.et V.) & $3.49 \%$ & $10.41 \%$ & $\begin{array}{c}\text { Coilia brachygnathus Kreyenberg } \\
\text { et Pappenheim }\end{array}$ & $3.78 \%$ & $1.17 \%$ \\
\hline Aristichthys nobilis (Rich.) & $1.80 \%$ & $4.65 \%$ & Squalidus argentatus & $1.15 \%$ & $0.07 \%$ \\
\hline Elopichthys bambusa (Rich.) & $0.61 \%$ & $0.51 \%$ & Saurogobio dabryi Bleeker & $4.00 \%$ & $0.56 \%$ \\
\hline Cyprinus (Cyprinus) carpio Linnaeus & $5.80 \%$ & $25.53 \%$ & Rhinogobio typus Bleeker & $0.68 \%$ & $0.25 \%$ \\
\hline Carassius auratus auratus (L.) & $5.94 \%$ & $3.05 \%$ & $\begin{array}{c}\text { Saurogobio gymnocheilus Lo, } \\
\text { Yao et Chen }\end{array}$ & $0.36 \%$ & $0.02 \%$ \\
\hline Parabramis pekinensis (Basilewsky, 1855) & $1.91 \%$ & $1.51 \%$ & Hemibarbus maculatus Bleeker & $0.97 \%$ & $0.58 \%$ \\
\hline Pseudobrama simoni (Bleeker) & $0.65 \%$ & $0.11 \%$ & Sinobdella sinensis & $0.29 \%$ & $0.03 \%$ \\
\hline Megalobrama skolkovii (Dybowski, 1872) & $0.32 \%$ & $0.41 \%$ & Mastacembelus armatus (Lac.) & $0.04 \%$ & $0.02 \%$ \\
\hline Megalobrama amblycephala Yih & $2.23 \%$ & $2.32 \%$ & Leptobotia taeniops (Savage) & $0.94 \%$ & $0.07 \%$ \\
\hline Xenocypris argentea Günther & $2.27 \%$ & $0.50 \%$ & Parabotia fasciata Dabry & $0.07 \%$ & $0.01 \%$ \\
\hline Xenocypris davidi Bleeker & $0.40 \%$ & $0.09 \%$ & Abbottina rivularis (Basilewsky) & $1.51 \%$ & $0.07 \%$ \\
\hline Squaliobarbus curriculus (Rich.) & $3.85 \%$ & $3.56 \%$ & Channa argus (Cantor) & $1.33 \%$ & $1.27 \%$ \\
\hline Culter alburnus Basilewsky & $4.32 \%$ & $8.99 \%$ & Pelteobagrus vachelli (Rich.) & $0.11 \%$ & $0.03 \%$ \\
\hline Culter mongolicus Basilewsky & $2.63 \%$ & $2.21 \%$ & Pelteobagrus fulvidraco (Rich.) & $4.47 \%$ & $0.90 \%$ \\
\hline Culter dabryi & $0.68 \%$ & $0.34 \%$ & Pelteobagrus nitidus (S.et D.) & $3.49 \%$ & $1.48 \%$ \\
\hline Cultrichthys erythropterus & $1.62 \%$ & $1.29 \%$ & Pelteobagrus eupogon (Boulenger) & $0.40 \%$ & $0.11 \%$ \\
\hline Erythroculter dabryi (Bleeker) & $0.07 \%$ & $0.04 \%$ & Mystus macropterus (Bleeker) & $0.43 \%$ & $0.13 \%$ \\
\hline $\begin{array}{c}\text { Erythroculter oxycephaloides } \\
\text { (Kreyenberg et Pappenheim, 1908) }\end{array}$ & $0.47 \%$ & $0.62 \%$ & $\begin{array}{l}\text { Pseudorasbora parva } \\
\text { (Temminck et Schlegel) }\end{array}$ & $3.49 \%$ & $0.23 \%$ \\
\hline Hemiculter leucisculus (Basil.) & $4.07 \%$ & $0.56 \%$ & Acheilognathus macropterus (Bleeker) & $1.98 \%$ & $0.16 \%$ \\
\hline Hemiculter bleekeri (Warpachowski, 1887) & $1.62 \%$ & $0.13 \%$ & Odontobutis obscurus (T.et S.) & $0.14 \%$ & $0.01 \%$ \\
\hline Rhodeinae & $0.43 \%$ & $0.04 \%$ & Leiocassis longirostris Günther & $0.11 \%$ & $0.50 \%$ \\
\hline Siniperca chuatsi (Basil.) & $1.15 \%$ & $0.60 \%$ & Leiocassis albomar ginatus Rendhal & $0.54 \%$ & $0.14 \%$ \\
\hline Siniperca kneri Garman & $0.32 \%$ & $0.78 \%$ & Opsariichthys bidens & $0.04 \%$ & $0.01 \%$ \\
\hline Siniperca asotus $\mathrm{L}$. & $1.51 \%$ & $3.54 \%$ & Pseudolaubuca sinensis Bleeker & $0.18 \%$ & $0.05 \%$ \\
\hline Silurus meridionalis Chen & $0.97 \%$ & $1.54 \%$ & Onychostoma barbatum (S. Y. Lin, 1931) & $0.07 \%$ & $0.02 \%$ \\
\hline Coreius heterodon (Bleeker) & $2.27 \%$ & $1.43 \%$ & others & $15.30 \%$ & $6.18 \%$ \\
\hline Hyporhamphus intermedius (Cantor) & $0.04 \%$ & $0.04 \%$ & & $100 \%$ & $100 \%$ \\
\hline
\end{tabular}

a high proportion of rare species and few abundant species have a species accumulation curve with a low inflection point on the y-axis and a long upward sloping line to the asymptote.

\subsection{Fish Fauna Composition}

The catches at the Dongting Lake Estuary were mainly composed of Lake settled fish. The biomass of Cyprinus (Cyprinus) carpio Linnaeus was the highest, 


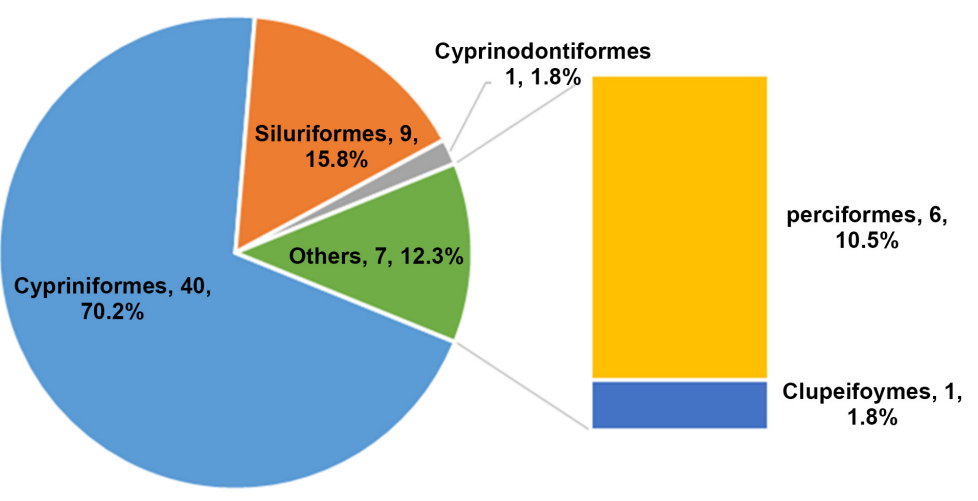

Figure 2. Percent of species number of each order to the total species in Dongting Estuary.

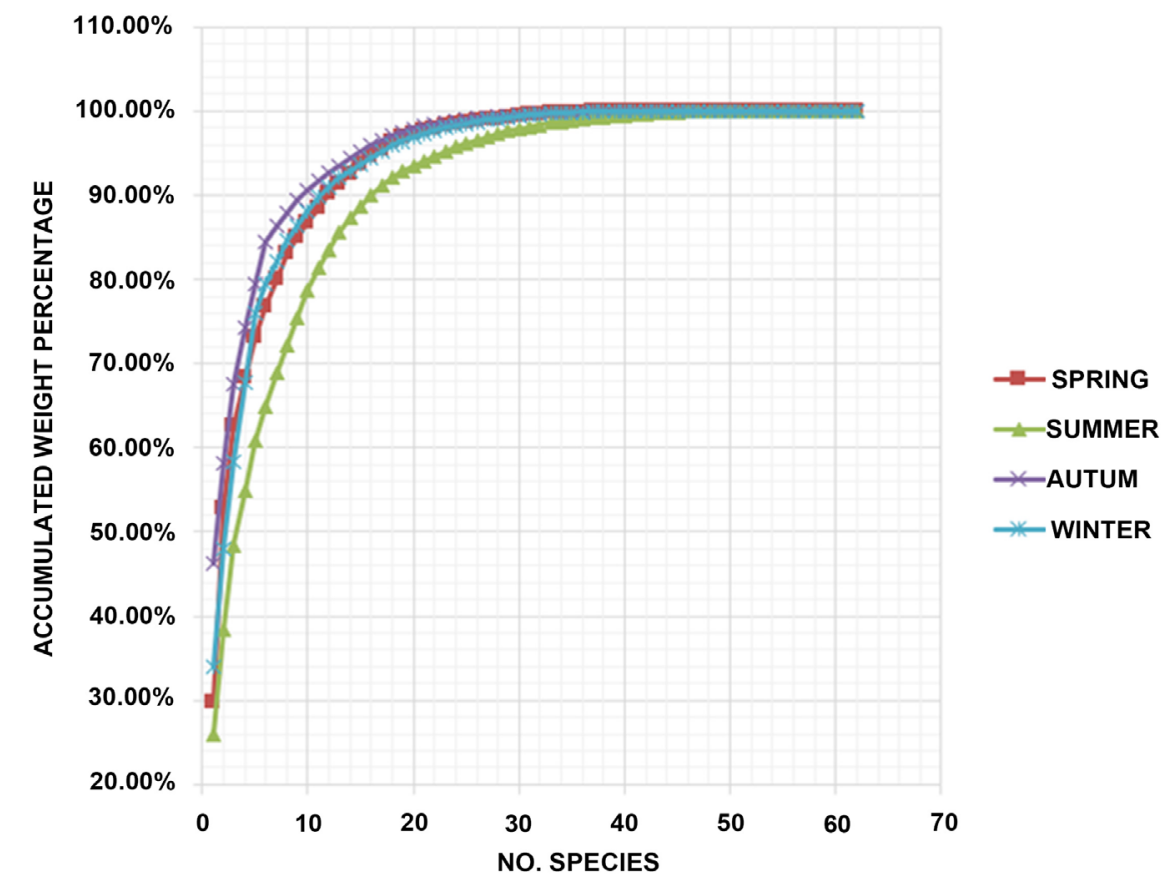

Figure 3. Sample-based rarefaction curve (solid line) with 95\% confidence intervals for all fish species recorded along the Dongting Estuary.

accounting for $25.53 \%$ of the total catches, followed by Culter alburnus Basilewsky, Ctenopharyngodon idellus, accounting for $10.41 \%, 8.99 \%$ and $7.10 \%$ of the total catches, respectively. Bighead carp (Hypophthalmichthys nobilis), silver carp (H. molitrix), black carp (Mylopharyngodon piceus) and grass carp (Ctenopharyngodon idella) accounted for $26.13 \%$ of the total catch (Table 1 ).

\subsection{Fish Diversity}

The abundance, biomass and richness varied seasonally depending on the cienaga, as well as between species. The range of richness of species (local richness) 
varied between 40 and 51 species, and according to the season of the year (Table 2 ). The trend was the smallest species in spring, with the arrival of summer and autumn gradually increasing, peaking at the turn of summer and autumn, and then gradually decreasing with the arrival of winter, to the lowest in spring. The Shannon, Simpson, Pielou and Margalef indices showed the consistent trends (Table 2).

\section{Discussion}

The Yangtze floodplain is among the largest floodplains in the world. Historically, all lakes in the floodplain were freely connected with the mainstem of the river. At present, only three medium- to large-sized lakes, Dongting Lake, Poyang Lake and Shijiu Lake, retain their free connection with the mainstem of the river. Such river-lake connections maked for the exchange of matter, energy and organisms between the river and its floodplain maintaining fish diversity in this region. The literature shows that Dongting Lake had 104 to 114 species of fish [13] [14] [15]. In this study, 57 species of fish were found in the annual monitoring of Dongting Lake estuary. Compared with historical data, there were fewer species.

Four major domestic carps (blue carp, grass carp, silver carp and Bighead carp) are drifting eggs. In the 1960s, the proportion of fish production in Dongting Lake reached 21\%, and then gradually declined (except in 1998 when a large-scale flood occurred). The years before the Three Gorges impoundment were between $8 \%$ and 9\%. From 2004 to 2009, the rapid decline period was caused by the changes of the hydrological situation and discharge of Dongting Lake after the closure of the Three Gorges. From 2010 to 2017 [16], it was the rising period of the four major domestic carps. The proportion of the Four major domestic carps in Dongting Estuary Lake in 2018 was 26.13\%, which was higher than that of Dongting Lake in history. This may be due to two reasons: 1) Since 2012, Hunan has increased the release of parent fish and fish species of the four major domestic carps in Dongting Lake and Xiangjiang River; 2) In recent years, the Dongting Lake region has strengthened its crackdown on illegal fishing.

Table 2. The biomass diversities calculated according to the total species in Dongting Estuary.

\begin{tabular}{ccccc}
\hline Indices & Spring & Summer & Autum & Winter \\
\hline No. of species & 42 & 48 & 51 & 40 \\
Shannon & 2.70 & 2.99 & 3.18 & 2.78 \\
Simpson & 0.8677 & 0.9107 & 0.9404 & 0.8519 \\
Pielou & 0.697237 & 0.809813 & 0.850799 & 0.708204 \\
Margalef & 5.867629 & 6.68866 & 6.080415 & 5.94163 \\
\hline
\end{tabular}


Species number and diversity indices showed that fish diversity of the Dongting Lake Estuary was high, with temporal variations. Generally, higher diversities occurred in summer and autumn than spring and winter. The periodic changes of fish species number and diversity indices in Dongting Lake estuary coincide with the periodic changes of flood peak and water level in Dongting Lake. Summer and autumn were the peak periods of floods. The Dongting Lake received the flood and got the supplement of fish resources, the species number and fish diversity indices reached the peak at this time. Then, with the recession of floods and the decline of water level, the number of species decreased gradually. The connection between rivers and lakes had play an important role in supplementing the fish resources of Dongting Lake and maintaining the fish diversity of Dongting Lake. The variation trend of diversity indices and evenness indice in Dongting Lake estuary was consistent, indicating that fish in Dongting Lake estuary enjoyed good niche differentiation. Both diversity index and evenness index were suitable for assessing the diversity status of fish in Dongting Lake.

\section{Conclusion}

An annual survey of fish was conducted in January to November 2018 in Dongting Lake Estuary. A total of 57 freshwater species and subspecies belonging to 5 orders and 10 families were recorded. The catches at the Dongting Lake Estuary were mainly composed of Lake settled fish. The four major domestic carps accounted for $26.13 \%$ of the total catch. The species, Shannon, Simpson, Pielou and Margalef indices, had the consistent trend, which was the fewer species in spring, with the arrival of summer and autumn gradually increasing, peaking at the turn of summer and autumn, and then gradually decreasing with the arrival of winter.

\section{Conflicts of Interest}

The authors declare no conflicts of interest regarding the publication of this paper.

\section{References}

[1] Wei, M. (2013) “Dongting Lake”. Famous Lakes in China. Huangshan Publishing House, Huangshan. (In English and Chinese)

[2] Ru, H.J. and Liu, X.Q. (2013) River-Lake Migration of Fishes in the Dongting Lake Area of the Yangtze Floodplain. Journal of Applied Ichthyology, 29, 594-601. https://doi.org/10.1111/jai.12116

[3] Liao, F.C., He, W., Huang, X.R., et al. (2002) Current Status and Changes of Fishery in Dongting Lake. Journal of Hydrobiology, 26, 623-627.

[4] Liao, F.C., He, X.C., He, W., et al. (2006) Current Status and Protection Strategies of Fishery Resources and Ecological Environment in Dongting Lake. Journal of Yueyang Vocational and Technical College, 21, 32 -37

[5] Wang, X.Y. and Liu, X.W. (2008) Preliminary Analysis of Major Ecological and 
Environmental Problems in the Dongting Lake Area. People's Yangtze River, 39, 105-107.

[6] Li, J.Q. (2013) Ecological Study on Fish Community and Conservation Strategies in Dongting Lake. Master's Dissertation, Central South University of Forestry \& Technology, Changsha.

[7] Chu, X.L., Zheng, B.S. and Dai, D.Y. (Eds.) (1999) Fauna Sinica, Osteichthyes, Siliuriformes. Science Press, Beijing. (In Chinese)

[8] Fish Research Laboratory, Hubei Institute of Aquatic Biology (1995) Yangtze River Fish [m]. Science Press, Beijing.

[9] Hubei Institute of Hydrobiology (1976) The Fishes of Yangtze River. Science Press, Beijing.

[10] Hunan Institute of Fisheries Science (1980) Hunan Fish Science. Hunan Science and Technology Press, Changsha.

[11] Shanon, C.E. and Weaver, W. (1963) The Mathematical Theory of Communication. University of Illinois Press, Urbana.

[12] Thompson, G.G. and Withers, P.C. (2003) Effect of Species Richness and Relative Abundance on the Shape of the Species Accumulation Curve. Austral Ecology, 28, 355-360. https://doi.org/10.1046/j.1442-9993.2003.01294.x

[13] Ru, H.J., Liu, X.Q., Huang, X.R., et al. (2008) Fish Species Diversity and Its Spatial and Temporal Variation in the Dongting Lake of a Large Tongjiang Lake. Journal of Lake Science, 20, 93-99. https://doi.org/10.18307/2008.0114

[14] Dou, H.S. and Jiang, J.H. (2000) Dongting Lake. China Science and Technology Press, Beijing, 1-54.

[15] Tang, J.H. and Qian, M.Q. (1979) Fish Fauna of Dongting Lake. Freshwater Fishery, 10, 24-32.

[16] Hunan Institute of Fisheries Science (2000-2017) Annual Report on Fishery Resources and Environmental Monitoring of Dongting Lake and the Jijiang River Section of the Yangtze River. 